\title{
THE IMPACT OF SERVICE QUALITY AND CORPORATE REPUTATION TOWARD LOYALTY IN THE INDONESIAN HOSPITALITY SECTOR
}

\author{
Nicholas Wilson \\ Faculty of Social Sciences and Humanities, Department of Management, Bunda Mulia University, Jakarta \\ Email:nwilson@bundamulia.ac.id
}

Masuk : 13-01-2020, revisi: 15-04-2020, diterima untuk diterbitkan : 15-04-2020

\begin{abstract}
ABSTRAK
Penelitian ini dilakukan guna mengetahui bagaimana pengaruh service quality dan corporate reputation terhadap loyalty, baik secara langsung ataupun tidak langsung melalui trust. Penelitian ini mengimplementasikan metode survei, dimana, kuesioner digunakan sebagai alat untuk mengumpulkan data yang diperlukan pada penelitian ini. Sebanyak 200 responden berpartisipasi pada penelitian ini, dimana, dari 200 data yang terkumpul, sebanyak 191 data dinyatakan valid, reliable dan dapat digunakan untuk selanjutnya diproses pada penelitian ini. Data selanutnya dianalisa dengan metode partial least squares-structural equation modelling (PLS-SEM). Berdasarkan hasil analisis data yang diperoleh, peneliti dapat menyimpulkan bahwa service quality dan corporate reputation berpengaruh positif terhadap loyalty, baik secara langsung ataupun tidak langsung melalui trust pada industri Perhotelan di Indonesia.
\end{abstract}

Kata Kunci: Service Quality, Corporate Reputation, Customer Loyalty, Trust, Indonesian Hospitality Sector

\section{ABSTRACT}

This research was conducted in order to determine the impact of service quality and corporate reputation toward customer loyalty, both directly and indirectly through trust in the Indonesian hospitality sector. This research implements ssurvey method, in which quaestionnaires were utilized as the tools to collect all of the data required for the completion of this study. A total od 200 respondents participate in this study, in which, out of 200, 191 data had been deemed valid, reliable and usable to be further processed in this research. All of the data then were analyzed using partial least squares-structural equation modeling (PLS-SEM) method. Based on the results of the data analysis, author would like to conclude that both service quality and corporate reputation had a positive impact on customer loyalty, both directly and indirectly through trust in the Indonesian hospitality sector.

Keywords: Service Quality, Corporate Reputation, Customer Loyalty, Trust, Indonesian Hospitality Sector.

\section{INTRODUCTION}

\section{Research Introduction}

Loyalty had been extensively studied or determined to be one of the most important factor or variable which could crucially determine a company's success in the market, regardless of the industry (Sivadas \& Baker-Prewitt, 2000). It is mainly because loyalty, unlike any other variables, serve as an important determinant which, not only could affect people's judgement toward the company, but could also determine a company's survival on the industry by affecting customers' perception and action as to whether or not customers will buy or use the same product or service manufactured or sold by the company repeatedly (Caruana, 2002; Yee et al., 2010; Nyadzayo \& Khajehzadeh, 2016). If a company failed to induce loyalty in the consumers' mind, then there's a chance or risk that consumers could move out to search for the same or similar products/services sold by the competitors. Thus, regarding this scenario, it is safe to say that there's a chance that the company will be "left behind" by it's competitors when they've successfully snatch or make the consumers move in their direction, since not only that customers are the main sources of income for the company (since they're the one who pay the products/services sold or offered by a company), but also because customers are the main factors which could drive the success of the company in the long term. Therefore, talking or discussing 
about loyalty, people shouldn't perceive it as a tool which could be utilized only in order to attract and make people buy our products or services but also as an important tool which could affect people or consumers' intention to further re-purchase or re-buy the products or services form the exact same company in the future. Furthermore, loyalty should also be understood as an important aspect which could retain the number of customers that a company had, and preventing them from buying the products or services sold by the competitors. Moreover, loyalty could also serve as an important and critical aspect which could affect the company's capability of maintaining and gaining a larger amount of market share in the market and the industry (Chang et al., 2009). Therefore, every single company in this world, regardless of the industry, should be able to understand the massive importance of loyalty in order to achieve their goals and success within the industry.

Previous studies had underlined the importance of service quality, corporate reputation and trust in affecting customer loyalty in the hospitality or the hotel industry all around the world. Could be understood as how people perceive and compare the quality of the service performed or offered by a hotel with their own expectation, service quality has topped the rank as perhaps one of the most important aspect which could determine a company's success within the service industry, an industry which, unlike the other industry, put more emphasize on the form and quality of the services offered to consumers rather than the products sold to consumers (Akbaba, 2006; Quinn et al., 2009; Keith and Simmers, 2013). And hotel industry is certainly and undoubtedly fall into this category. Despite offering and selling certain types of products to all of it's guests, people still exclusively judge the quality and the credibility of a hotel not from the tangible products that it sold, but mainly from the quality or the form of service offered to the consumers (or guests). It is mainly because despite for the fact that people are coming to a hotel for various reasons (for examples: stay, meeting, swim, or even for having a breakfast, lunch or dinner), people had a strong tendency to take a more detailed look at the courtesy and the manner shown by the staffs in catering all of the consumers' needs rather than looking at the quality of the tangible aspects offered by the hotel. Furthermore, people or consumers also had a strong tendency to compare the quality performed at one hotel to another (competitors), which make service quality an important factor which shouldn't be overlooked by companies specializing in the service sector all across the world (Victorino et al., 2005; Wu and Ko, 2013).

Meanwhile, corporate reputation could also perceived as an equally important role which could affect people's judgement toward the brand or a company, which could ultimately affect their thought on whether or not they will stay in the same hotel in the future. Defined as people's judgements toward certain brands or companies, coeporate reputation also plays a crucial role in affecting people's intention to re-stay in the same hotel in the future due to the fact that it could alter people's thoughts, judgements or even attitude toward the brand or company. In regard with this concept, there will be a strong probability or possibility that people will buy or use (and ultimately re-buy) the product manufactured or sold by companies which had a positive reputation in the market as compare to those which reputation was deemd as negative or bad due to some unethical, illegal or irresponsible activities conducted by the company. Therefore, every single companies should pay a thorough attention regarding the importance of establishing and maintaining a positive reputation in the market in otder to boost people's confidence and willingness to conduct transactional activities toward the companies. Furthermore, companies ability to offer the highest level of quality regarding the service performed to consumers, together with the companies ability to establish and and maintain a positive reputation will more likely to result in the companies' ability to induce trust in the consumers' minds, which inturns could positively affect people's assessment and loyalty toward the company. Based on the 
introduction stated above, author would like to understand the role of both service quality and corporate reputation in affecting consumers' loyalty in the Indonesian hotle industry, both directly and indirectly through trust.

\section{Literature Review and Hypotheses Development Service Quality}

Service quality could be defined as people's judgement toward the quality of the service performed by a company (Johnston, 1995; Santos, 2003). Furthermore, service quality could also be understood as people's personal comparison between the expectation that they had regarding the form or quality of the service that is about to be performed by the company with the real service performed and felt by the consumers at a specific time and place (Parasuraman et al., 2005). Moreover, service quality could also be understood people or consumers' perception regarding the quality of the service offered or conducted by the company relative with the similar service offered by the other companies or competitors (Collier and Bienstock, 2006).

\section{Corporate Reputation}

Corporate reputation could be understood as people or public's perception toward the company which derived from people's judgement regarding all of the activities conducted by a company in the market (Caruana and Ewing, 2010). Furthermore, corporate reputation could also be understood as people or public's collective assessments or perceptions toward a company which based on whether or not people or public view the activities conducted or performed by the company is ethical (Nguyen and Leblanc, 2001; Chang, 2013).

\section{Trust}

Trust could be defined as people or public's willingness to involve or take any risks associated with doing some transactional activities toward a company (Harris and Goode, 2004; Victorino et al., 2005). Moreover, trust could also be defined as people or consumers' personal belief that a company would and could fulfill their demand, or fulfill what had been promised to the consumers beforehand (Zahedi and Song, 2008; Choi and La, 2013; Rasheed and Abadi, 2014).

\section{Customer Loyalty}

Loyalty could be defined as people of consumers' willingness, not only to engage in transactional activities with a company, but also to re-engage in the further transactional activities toward the same company (Wilson, 2018). Furthermore, loyalty could also be understood as consumers' unwillingness to buy, use or purchase similar products or services from the other companies (competitors) (Anwar et al., 2011; He et al., 2012). Similarly, Yee et al., (2010) also define Customer loyalty as people's personal action of keep buying products or services from the same company, while recommending the company to the other people or colleagues at the same time.

\section{The Direct and Indirect Impact of Service Quality and Corporate Reputation on Loyalty through Trust}

Previous studies by Helm (2007) and Chang (2013 had found out that corporate or company's reputation could positively affect customer loyalty, in which it affects people's intention to revisit, re-consume or re-buy the products sold by the same company in the future. Furthermore, another studies conducted by Nguyen (2001) and De Leaniz and Del Bosque Rodríguez (2016) also confirm that corporate image and reputation had a positive direct impact on people's loyalty toward the firm. Similarly, previous study by Chang (2013) also found that trust, together with reputation had a positive impact on loyalty. 
In the other hand, regarding the impact of service quality on trust and loyalty, previous studies conducted by both Kassim and Asiah Abdullah (2010) and Zehir et al., (2011) confirmed that both service quality and trust had a positive impact on customer and brand loyalty. Furthermore, another study by Sivadas and Baker-Prewitt (2000) also uncover the relationship between service quality and loyalty, in which, both service quality and satisfaction have a significant impact on people's loyalty in re-visiting the same store or place in the futute. Furthermore, Segoro (2013) also found that service quality had a positive impact in increasing both the satisfaction and loyalty in the consumers' minds. Based on the previous studies explained and stated above, author would like to posit several hypotheses in this research:

H1: Service Quality had a positive impact on Customer Loyalty

H2: Corporate Reputation had a positive impact on Customer Loyalty

H3: Service Quality had a positive impact on Customer Loyalty through Trust

H4: Service Quality had a positive impact on Customer Loyalty through Trust

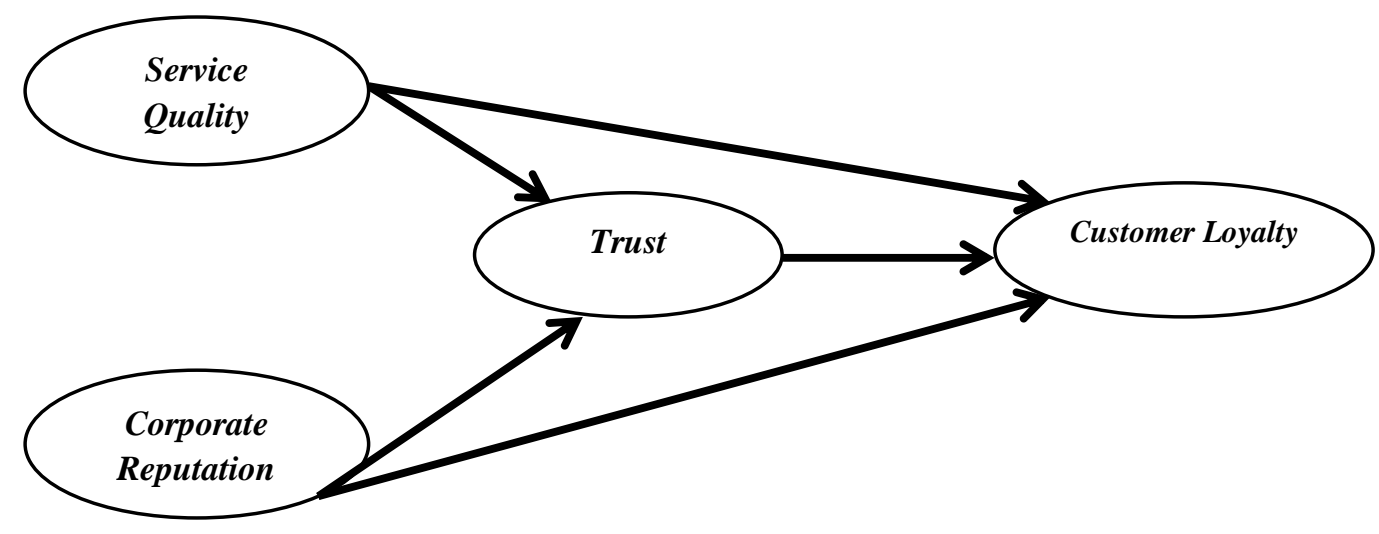

Figure 1. Research Model

Sources: Author's Personal Conception (2020)

\section{RESEARCH METHODOLOGY}

This research utilizes survey method, in which questionnaire was chosen as the instrument to collect all of the data needed for this research. There are two parts in this questionnaire, in which the first part contains the questions regarding the demographics of the respondents. In the other hand, the second part of this questionnaire contains a total of 25 items which represent all 3 variables analyzed in this research. From the total of 25 items, 15 items representing variable Service Quality (which consisted of five (5) SERVQUAL dimensions) were adapted from Wilson et al., (2019); 5 items represent variable Corporate Reputation were adapted from, and 5 items which represent variable Customer loyalty were adapted from.

Furthermore, Interval scale with 5-Point Likert Scale method was also used in this research, in which each respondent was asked to give their respond regarding each statement presented on the second part of this questionnaire, which was consisted of "1" to reflect their strong disagreement toward the statement, "2" to reflect their disagreement toward the statement, " 3 " to reflect that they are neither agree nor disagree toward the statement, "4" to reflect their agreement toward the statement, and " 5 " to reflect their strong agreement toward the statement. 
Regarding the amount of sample size determined in this research, Hair et al. (2010) stated that a total between 150 to 400 sample size were the right number for a research or study using both structural equation modeling and partial least squares-structural equation modeling approach (PLS-SEM). Moreover, Wilson \& Makmud (2018) had also stated that for a multivariate research, a total of sample size between 150 to 300 respondents had been deemed appropriate. Furthermore, previous research by Zhou et al., (2009) also underlined that for a research, the total number of sample size determined by researchers should exceed 200. Based on the theories stated above, a total of 200 sample size was determined and set for this research.

A total of 200 respondents participated in this research, in which, respondents who were chosen are the those who've visited either a four or five-star hotels which are located in all across Indonesia for at least three times in the past two years (regardless of the respondents' reasons to visit the hotel). Furthermore, the data used in this research were collected from respondents who lived in Jakarta and Tangerang. After distributing all of the questionnaires to all pre-determined respondents, author would like to conclude that the response rate of this research is $100 \%$ since all 200 questionnaires were completely filled and returned. After further assessment was made regarding the response given in the questionnaires, all data generated from the questionnaires were deemed valid and usable. Therefore, data collected from a total of 200 questionnaires were used and processed in this research.

Based on the results of the data analysis regarding the profile of the respondents, Most of the respondents are male (57\%), and most of them are staying at the hotel for leisure or vacation purpose (64\%). After conducting the demographics analysis on the respondents, data were then analyzed using partial least square-structural equation modeling (PLS-SEM) using SmartPLS 3.2.8 software in order to determine the validity and reliability of the model, and to determine the relationship between variables.

\section{RESULTS AND DISCUSSIONS}

All of the data from the questionnaires were processed using Partial Least Squares-Structural Equation Modeling (PLS-SEM) method by using SmartPLS 3.2.8 software. Using PLS-SEM method, the outer model and inner model measurement needed to be conducted to determine the relationship between variables and to test the hypotheses proposed in this research

\section{Outer Model and Inner Model Analysis}

The outer model analysis need to be assessed beforehand in order to confirm the validity and the reliability of the model. In the outer model analysis, several criteria needed to be fulfilled in order for a model to be classified as valid and reliable, and in order for the inner model analysis to be conducted. Several criteria that required to be fulfilled are: The value of AVE should be above 0.5 and the value of AVE of each latent construct should be higher than the construct's highest squared correlation with any other latent construct (fornell-larcker criterion) as suggested by Zhou et al., (2009) and Hair et al., (2011); the factor loadings value of each indicators should exceed 0.5 as suggested by Barclay et al., (1995); and the value of both composite reliability and cronbach's alpha should be greater than 0.7 as suggested by Ebert (2010) and Peterson (1994).

Based on the results of the outer model analysis, it could be concluded that the model had fulfilled all criteria set or described in the outer model analysis. The factor loadings value of each items had exceeded the cut-off value of 0.50, while the AVE, cronbach's alpha and the composite reliability of all variables had exceeded the minimum acceptance value of $0.50,0.70$, 
and 0.70 respectively. Furthermore, the value of AVE of each latent construct had been higher than the construct's highest squared correlation with any other latent construct. Based on these results, it could be concluded that the data and the model had fulfilled all criteria set in the outer model analysis. Therefore, the inner model analysis could be further conducted on the data and the model. Furthermore, after completing the outer model analysis, the inner model analysis was further conducted on the data and the model in order to determine the relationship between variables. Moreover, data generated from the inner model analysis will be used as a benchmark in terms of whether the hypotheses proposed or posited in this research were supported or rejected. By implementing 5\% of significance level, the cut-off value of 1.96 was set in this analysis in order to determine whether the hypotheses were supported or rejected. Based on the results generated on the inner model analysis, it was revealed that the t-value of all hypotheses had exceeded the cut-off value of 1.96. which could be seen as a valid and unquestionable sign that all hypotheses which are proposed in this research had been supported.

Table 1

Path Coeffciient Analysis and Hypotheses Testing Results Source: Data Analysis (2019)

\begin{tabular}{cccc}
\hline Relationships & T-Statistics & Conclusions & $\begin{array}{c}\text { Hypotheses } \\
\text { Testing } \\
\text { Conclusions }\end{array}$ \\
\hline $\begin{array}{c}\text { Service Quality had a Positive Impact on } \\
\text { Customer Loyalty }\end{array}$ & 3.143 & Significant & H1 Supported \\
\hline $\begin{array}{c}\text { Customer Loyalty } \\
\text { Corporate Reputation had a Positive Impact on }\end{array}$ & 2.247 & Significant & H2 Supported \\
\hline $\begin{array}{c}\text { Service Quality had a Positive Impact on } \\
\text { Customer Loyalty through Trust }\end{array}$ & 2.836 & Significant & H3 Supported \\
\hline $\begin{array}{c}\text { Corporate Reputation had a Positive Impact on } \\
\text { Customer Loyalty through Trust }\end{array}$ & 2.908 & Significant & H4 Supported
\end{tabular}

\section{Discussions}

This research was conducted in order to determine whether or not both service quality and corproste reputation play important and significant role in affecting customer loyalty in the Indonesian hospitality industry, both directly and indirectly through trust. Based on the results of the data analysis, it could be concluded that both service quality and corporate reputation had a positive impact on customer loyalty, both directly and indirectly through trust. These results further prove the importance of both variables in retaining and inducing loyalty in the consumers' mind in the Indonesian hospitality industry. Since most of the aspects presented or offered by a hotel is intangible, people have a tendency to judge the quality of the hotel from the service that was offered to them, rather than judging the quality of the hotel based on the tangible goods or aspects possessed by the hotel. Therefore, every single hotel managers all around Indonesia need to understand the importance of maintaining and improving the service offered to the consumers all the time in order ot ensure that the exct same consumers will re-visit the hotel again (regardless of the reason) in the future. Improving or enhancing the quality of the service offered to consumers could also serve as an important factor which could prevent customers or guests to visit or stay in the other hotel in the future. Furthermore, since corporate reputation also turned out to be another variable which could positively affect people's loyalty toward the hotel, 
each and every single hotels operating in Indonesia should be able to establish, maintain and enhance the positive reputation that they had in order to further convince people and potential customers that all of the activities and policies conducted and implemented by the hotels have followed or are in accordance with all of the ethical and moral aspects believed by the public to be positive, which in the end could enhance the positive reputation possessed by the hotel, thus ensuring people's favourability toward the hotel as compared to the other hotels in the industry. Furthermore, maintaining and improving the quality of the service offered to consumers, while improving the positive reputation possessed by the hotel at the same time could also increase the level of trust in people's minds toward the hotel, which in turns could make people to be loyal to the hotel, while preventing them to "take a look" at the other hotels in the future.

\section{CONCLUSIONS AND SUGGESTIONS}

This research was conducted in order to determine whether or not both service quality and corproate reputation play important and significant role in affecting customer loyalty in the Indonesian hospitality industry, both directly and indirectly through trust. Based on the results of the data analysis, author would like to conclude that both service quality and corporate reputation had a positive impact on customer loyalty, both directly and indirectly through trust in the Indonesian hospitality sector. Therefore, based on these conclusions, author suggest that hotels all around Indonesia could keep improving, enhancing and maintaining the quality of their service, while improving people's favouritism toward the reputation of the hotel in order to ensure that people will keep going, staying or visiting the hotel in the future.

Despite the rigorous and thorough nature of this research, several limitations still exist in this research. First of all, this research was conducted only in Jakarta dn Tangerang, which might hamper the generalizability of this research. Therefore, author suggest that future researchers could conduct another study (using this topic) in the other region or even country outside Indonesia, in order to enhance the variability of this topic. Moreover, this research was conducted in the Indonesian hospitality industry, which might render the results of this research unable to be generealized to the other industries. Therefore, author strongly suggests to future researchers to conduct or examine the impact of the variables assessed in this study in the other industries in order to increase the generalizability of this study.

\section{REFERENCES}

Akbaba, A. (2006). Measuring service quality in the hotel industry: A study in a business hotel in Turkey. International Journal of Hospitality Management, 25(2), 170-192. https://doi.org/10.1016/j.ijhm.2005.08.006

Anwar, A., Gulzar, A., Sohail, F. Bin, \& Akram, S. N. (2011). Impact of Brand Image, Trust and Affect on Consumer Brand Extension Attitude: the Mediating Role of Brand Loyalty. International Journal of Economics and Management Sciences, 1(5), 73-79.

Barclay, D., Higgins, C., and Thompson, R. (1995), The partial least squares (PLS) approach to casual modeling: Personal computer adoption and use as an illustration, Technology Studies, 2(2), 285-309.

Caruana, A. (2002). Service loyalty: The effects of service quality and the mediating role of customer satisfaction. European Journal of Marketing, 36(7/8), 811-828 https://doi.org/10.1108/03090560210430818

Caruana, A., \& Ewing, M. T. (2010). How corporate reputation, quality, and value influence online loyalty. Journal of Business Research, 63(9/10), 1103-1110 https://doi.org/10.1016/j.jbusres.2009.04.030 
Chang, H. H., Wang, Y. H., \& Yang, W. Y. (2009). The impact of e-service quality, customer satisfaction and loyalty on e-marketing: Moderating effect of perceived value. Total Quality Management and Business Excellence, 20(4), 423-443 https://doi.org/10.1080/14783360902781923

Chang, K. C. (2013). How reputation creates loyalty in the restaurant sector. International Journal of Contemporary Hospitality Management, 25(4), 536-557. https://doi.org/10.1108/09596111311322916

Choi, B., \& La, S. (2013). The impact of corporate social responsibility (CSR) and customer trust on the restoration of loyalty after service failure and recovery. Journal of Services Marketing, 27(3), 223-233. https://doi.org/10.1108/08876041311330717

Collier, J. E., \& Bienstock, C. C. (2006). Measuring service quality in E-retailing. Journal of Service Research. https://doi.org/10.1177/1094670505278867

De Leaniz, P. M. G., \& Del Bosque Rodríguez, I. R. (2016). Corporate Image and Reputation as Drivers of Customer Loyalty. Corporate Reputation Review, 8(3), 260-275. https://doi.org/10.1057/crr.2016.2

Ebert, T. (2010). Trust as the Key to Loyalty in Business-to-Consumer Exchanges: Trust Bulding Measures in the Banking Industry. Frankfurt/Main: Springer Science and Business Media.

Hair, J.F., Ringle, C.M., \& Sarstedt, M. (2011). PLS-SEM: Indeed a Silver Bullet. The Journal of Marketing Theory and Practice. 19(2), 139-151.

Harris, L. C., \& Goode, M. M. H. (2004). The four levels of loyalty and the pivotal role of trust: A study of online service dynamics. Journal of Retailing, 80(2), 139-158. https://doi.org/10.1016/j.jretai.2004.04.002

He, H., Li, Y., \& Harris, L. (2012). Social identity perspective on brand loyalty. Journal of Business Research, 65(5), 648-657. https://doi.org/10.1016/j.jbusres.2011.03.007

Helm, S. (2007). The Role of Corporate Reputation in Determining Investor Satisfaction and Loyalty. Corporate Reputation Review, 10(1), 22-37. https://doi.org/10.1057/palgrave.crr.1550036

Johnston, R. (1995). The Determinants of Service Quality: Satisfiers and Dissatisfiers. International Journal of Service Industry Management, 6(5), 53-71. https://doi.org/10.1108/09564239510101536

Kassim, N., \& Asiah Abdullah, nor. (2010). The effect of perceived service quality dimensions on customer satisfaction, trust, and loyalty in e-commerce settings: A cross cultural analysis. Asia Pacific Journal of Marketing and Logistics, 22(3), 351-371. https://doi.org/10.1108/13555851011062269

Keith, N. K., \& Simmers, C. S. (2013). Measuring hotel service quality perceptions: The disparity between comment cards and LODGSERV. Academy of Marketing Studies Journal, 17(2), 119-132.

Nguyen, N., \& Leblanc, G. (2001). Corporate image and corporate reputation in customers' retention decisions in services. Journal of Retailing and Consumer Services, 8(4), 227236. https://doi.org/10.1016/s0969-6989(00)00029-1

Nyadzayo, M. W., \& Khajehzadeh, S. (2016). The antecedents of customer loyalty: A moderated mediation model of customer relationship management quality and brand image. Journal of Retailing and Consumer Services, 30, 262-270. https://doi.org/10.1016/j.jretconser.2016.02.002

Parasuraman, A., Zeithaml, V. A., \& Malhotra, A. (2005). E-S-QUAL a multiple-item scale for assessing electronic service quality. Journal of Service Research, 7(3), 213-233. https://doi.org/10.1177/1094670504271156 
Peterson, R.A. (1994). A Meta-analysis of Cronbach's coefficient alpha. Journal of Consumer Research. 21(2), 381-391.

Quinn, A., Lemay, G., Larsen, P., \& Johnson, D. M. (2009). Service quality in higher education. Total Quality Management and Business Excellence, 20(2), 139-152. https://doi.org/10.1080/14783360802622805

Rasheed, F. A., \& Abadi, M. F. (2014). Impact of Service Quality, Trust and Perceived Value on Customer Loyalty in Malaysia Services Industries. Procedia - Social and Behavioral Sciences, 164, 298-304. https://doi.org/10.1016/j.sbspro.2014.11.080

Santos, J. (2003). E-service quality: A model of virtual service quality dimensions. Managing Service Quality: An International Journal, 13(3), 233-246. https://doi.org/10.1108/09604520310476490

Segoro, W. (2013). The Influence of Perceived Service Quality, Mooring Factor, and Relationship Quality on Customer Satisfaction and Loyalty. Procedia - Social and Behavioral Sciences, 81, 306-310. https://doi.org/10.1016/j.sbspro.2013.06.433

Sivadas, E., \& Baker-Prewitt, J. L. (2000). An examination of the relationship between service quality, customer satisfaction, and store loyalty. International Journal of Retail \& Distribution Management, 28(2), 73-82. https://doi.org/10.1108/09590550010315223

Victorino, L., Verma, R., Plaschka, G., \& Dev, C. (2005). Service innovation and customer choices in the hospitality industry. Journal of Service Theory and Practice, 15(6), 555576. https://doi.org/10.1108/09604520510634023

Wilson, N. (2018). The Impact of Service Quality and Brand Image Toward Customer Loyalty in The Indonesian Airlines Industry, Jurnal Manajemen Indonesia. 18(3), 222-234. https://doi.org/10.25124/jmi.v18i3.1734

Wilson, N., \& Makmud, S.T. (2018). The Impact of Brand Evaluation, Satisfaction, Brand Relationship and Trust To Brand Loyalty: A Case Study of The Indonesian Smartphone Industry, Jurnal Muara Ilmu Sosial, Humaniora, dan Seni, 2(2), 633-649. http://dx.doi.org/10.24912/jmishumsen.v2i2.2077

Wilson, N., Keni, K., and Tan, P.H.P. (2019). The Effect of Website Design Quality and Service Quality on Repurchase Intention in the E-commerce Industry: A Cross-Continental Analysis, Gadjah Mada International Journal of Business, 21(2), 187-222. https://doi.org/10.22146/gamaijb.33665

Wu, H. C., \& Ko, Y. J. (2013). Assessment of Service Quality in the Hotel Industry. Journal of Quality Assurance in Hospitality and Tourism, 14(3), 21-244. https://doi.org/10.1080/1528008X.2013.802557

Yee, R. W. Y., Yeung, A. C. L., \& Edwin Cheng, T. C. (2010). An empirical study of employee loyalty, service quality and firm performance in the service industry. International Journal of Production Economics, 124(1), 109-120. https://doi.org/10.1016/j.ijpe.2009.10.015

Zahedi, F. M., \& Song, J. (2008). Dynamics of trust revision: Using health infomediaries, Journal of Management Information Systems, 24(4), 225-248.

Zehir, C., Şahin, A., Kitapçi, H., \& Özçahin, M. (2011). The effects of brand communication and service quality in building brand loyalty through brand trust; the empirical research on global brands. Procedia - Social and Behavioral Sciences, 24, 1218-1231. https://doi.org/10.1016/j.sbspro.2011.09.142

Zhou, T., Lu, Y., \& Wang, B. (2009). The relative importance of website design quality and service quality in determining consumers' online repurchase behavior. Information Systems Management, 26(4), 327-337. https://doi.org/10.1080/10580530903245663 